\title{
Regulatory Mutations Affecting the Synthesis of Pectate Lyase in Erwinia chrysanthemi
}

\author{
By NICOLE HUGOUVIEUX-COTTE-PATTAT, * \\ SYLVIE REVERCHON, GUY CONDEMINE AND \\ JANINE ROBERT-BAUDOUY \\ Laboratoire de Microbiologie, Bâtiment 406, Institut National des Sciences Appliquées, \\ 20 avenue Albert Einstein, 69621 Villeurbanne, France
}

(Received 27 November 1985 ; revised 14 February 1986)

\begin{abstract}
Erwinia chrysanthemi secretes five isoenzymes of pectate lyase (PLa to PLe), which are involved in the phytopathogenicity of this bacterial species. We describe the isolation and characterization of mutants in the regulatory systems controlling PL synthesis. The regulation of PL synthesis appears to be complex, involving several controls. In one class of mutants, designated cri, the synthesis of various proteins became resistant to catabolite repression. This mutation mainly affected the synthesis of isoenzymes PLb and PLc. In a second class of mutants, designated gpiR, PL synthesis was no longer inducible in the presence of pectin derivatives; the regulatory gene responsible for the induction was evidently inactivated. Moreover gpiR mutations led to synthesis of PL independent of the growth phase, whereas in the wild-type strain PL synthesis increased only at the end of exponential growth. These mutations mainly affected the synthesis of PLa, PLd and PLe. Mutations in $k d g R$, the regulatory gene controlling 2-keto-3-deoxygluconate catabolism, had the same effects on PL synthesis as gpiR mutations.
\end{abstract}

\section{INTRODUCTION}

Erwinia chrysanthemi is a phytopathogenic species of enterobacteria responsible for soft-rot disease in many plant species. Its pathogenicity is due chiefly to its pectinolysis of plant cell walls (Starr \& Chatterjee, 1972; Chatterjee \& Starr, 1980). Pectate lyases (PL; EC 4.2.2.2) are extracellular enzymes secreted by the bacteria (Andro et al., 1984), which catalyse the transeliminative cleavage of pectin and its demethylated product, polygalacturonate (PGA). The extracellular PL of E. chrysanthemi account for the processes of tissue maceration and cell killing, which are characteristics of soft-rot diseases (Bashman \& Bateman, 1975).

Several features of the regulation of PL synthesis have been described at the physiological level. PL are inducible enzymes; induction by pectin and PGA is mediated by reaction products of extracellular pectic enzymes (Collmer \& Bateman, 1981). The action of pectate and oligogalacturonate lyases on PGA leads to the formation of 5-keto-4-deoxyuronate (DKI). DKI is isomerized to 2,5-diketo-3-deoxygluconate (DKII) which is reduced to 2-keto-3-deoxygluconate (KDG) (Condemine et al., 1984). KDG is then phosphorylated and cleaved to form pyruvate and triose phosphate (Hugouvieux-Cotte-Pattat \& Robert-Baudouy, 1985a). KDG and DKII are probably the real inducers of PL synthesis (Condemine et al., 1986). PL formation in Erwinia carotovora has been reported to be subject to catabolite repression (Hubbard et al., 1978). Moreover, in liquid cultures, the synthesis of polymer-degrading enzymes, such as PL or cellulases, increases at the end of exponential growth and therefore is dependent on the growth phase.

So far no regulatory mutations affecting PL synthesis have been described. We report here the isolation and characterization of three classes of such mutants.

Abbreviations: KDG, 2-keto-3-deoxygluconate; PGA, polygalacturonate; PL, pectate lyase(s). 
Strain

Table 1. Bacterial strains and plasmid

Erwinia chrysanthemi

B374

BL4

A733

BLU22

ERH202

RH6010

Plasmid

pULB 113
Genotype or phenotype

\author{
Wild-type \\ $\operatorname{lm} r T^{c}$ \\ $\operatorname{lm} r T^{\circ} \operatorname{lac} Z$ \\ $\operatorname{lmr} T^{\mathrm{c}}$ exuT $T^{\mathrm{c}}$ his-5 \\ exuT $T^{\mathrm{i}}$ his-5 $k d g A 2 \mathrm{Rif}^{\mathrm{R}}$ \\ thr-I leu-1 pro-l his-5 trp-l thyAl ile-I rpsLI Rif ${ }^{\mathrm{R}}$ \\ $\operatorname{tra}^{+}$bla $^{+}(\mathrm{TEM}-2) \mathrm{Tn} l$ tet $^{+} a p h A^{+}(\mathrm{Mu} 3 \mathrm{~A})$
}

Origin or reference

Hamon \& Peron (1961)

Spontaneous mutant of B374

NTG mutant of BL4

Hugouvieux-Cotte-Pattat et al. (1983)

Van Gijsegem et al. (1985)

Schoonejans \& Toussaint (1983)

Van Gijsegem \& Toussaint (1982)

\section{METHODS}

Strains. These are listed in Table 1. All the E. chrysanthemi strains originated from the wild-type strain B374 used previously. This strain synthesizes five major PL isoenzymes, PLa, PLb, PLc, PLd and PLe, differentiated by their isoelectric points and encoded by the genes pelA, pelB, pelC, pelD and pelE respectively (Van Gijsegem et al., $1985 b$ ). Strain B374 is unable to utilize lactose and glucuronate as carbon sources for growth. Spontaneous mutants which can use these sugars ( $\mathrm{Lac}^{+}$and $\mathrm{Gur}^{+}$, respectively) show derepressed synthesis of transport system proteins able to mediate the uptake of these sugars ( $\operatorname{lmr} T$ and exuT gene products, respectively) (HugouvieuxCotte-Pattat \& Robert-Baudouy, 1985b; Hugouvieux-Cotte-Pattat et al., 1983).

Media and growth conditions. Cells were usually grown at $30^{\circ} \mathrm{C}$ in complete medium $\mathrm{L}$ or in synthetic minimal medium M63 (Miller, 1972) supplemented with a carbon source $(0.2 \%)$ and when necessary with amino acids $\left(40 \mathrm{\mu g} \mathrm{ml}^{-1}\right)$. PGA grade II (Sigma) was added at $0.4 \%$ in solid medium; PGA grade III (Sigma) was used for induction and PL assays.

Enzyme assays. The total (intracellular and extracellular) PL activity was assayed after toluenization (Moran \& Starr, 1969) of cultures in the late-exponential phase $\left(\mathrm{OD}_{600}\right.$ about 3$)$. Activity was assayed spectrophotometrically at $235 \mathrm{~nm}$; an increase in absorbance of 5.2 was considered to represent the formation of $1 \mu \mathrm{mol}$ unsaturated uronide product in the reaction mixture (Moran et al., 1968).

The hexuronate transport system was assayed on whole cells as previously described (Hugouvieux-Cotte-Pattat et al., 1983). $\beta$-Galactosidase activity was measured on toluenized cells (Miller, 1972).

Soft-rot of potato tubers. Discs of potato were placed in Petri dishes containing a filter paper saturated with sterile water. A $10 \mu \mathrm{l}$ sample of a fresh overnight culture (about $10^{7}$ cells) of $E$. chrysanthemi was put on the surface of the potato discs. After incubation at $30^{\circ} \mathrm{C}$ for $24 \mathrm{~h}$, the extent of rot caused by the bacteria was examined.

Matings. Donors bearing the plasmid pULB113 and recipient strains were grown exponentially at $30^{\circ} \mathrm{C}$ in L broth. Samples $(0.2 \mathrm{ml}$ each) of recipient and donor were spread on M63 plates, without a carbon source, and incubated for $5 \mathrm{~h}$ at $30^{\circ} \mathrm{C}$. Bacteria were then collected by adding $1 \mathrm{ml} \mathrm{M} 63$ medium and spreading at the appropriate dilution on selective media (Van Gijsegem \& Toussaint, 1983).

Plate assay for detection of pectolytic activity. Isolated clones were replicated on solid M63 medium containing PGA as a pectolytic enzyme substrate. To minimize the inducing properties of PGA, this compound was sometimes added in a molten minimal soft agar and poured over the surface of the plate, after growth of the bacteria on glycerol minimal medium. After incubation at $30^{\circ} \mathrm{C}$, plates were stained by flooding with $10 \%(\mathrm{w} / \mathrm{v})$ copper acetate, which forms a blue complex with the polymer, leaving clear haloes around colonies that produce pectolytic enzymes (Reverchon et al., 1985).

Isolation of mutants. Chemical mutagenesis of strain BL4 was done with $N$-methyl- $N^{\prime}$-nitro- $N$-nitrosoguanidine (NTG) (Miller, 1972). The mutagenized cells were diluted and spread onto $L$ agar plates. After growth, they were replicated onto minimal medium containing PGA. Clones showing larger haloes (about twice the size of those of the parent strain) in the test for detection of pectolytic activity were retained.

Separation of $P L$ isoenzymes by electrofocusing. Ultrathin polyacrylamide gels were used for electrofocusing of cell extracts in the $\mathrm{pH}$ range 3.5-9.5. After protein separation, the PL activity was detected directly on the gel as described by Bertheau et al. (1984).

\section{RESULTS}

Isolation of mutants. NTG mutagenesis was performed on the $\mathrm{Lac}^{+}$strain $\mathrm{BL4}$, with a survival rate of $3 \%$. Out of 2000 clones, we found 49 auxotrophs, $14 \mathrm{Lac}^{-}$mutants and 6 mutants in which PL synthesis seemed to be derepressed, as indicated by the larger haloes in the test for detection of pectolytic activity. Out of 5000 other clones, we found 20 mutants affected in PL production. 
Table 2. PL production in Erwinia chrysanthemi mutants

\begin{tabular}{|c|c|c|c|c|c|}
\hline \multirow[b]{2}{*}{ Class } & \multirow[b]{2}{*}{$\begin{array}{l}\text { Strain } \\
\text { analysed }\end{array}$} & \multirow[b]{2}{*}{$\begin{array}{l}\text { Similar } \\
\text { strains }\end{array}$} & \multicolumn{2}{|c|}{ Growth conditions* } & \multirow{2}{*}{$\begin{array}{c}\text { PL } \\
\text { activity }\end{array}$} \\
\hline & & & Carbon source & Inducer & \\
\hline & B374 (wild-type) & & $\begin{array}{l}\text { Glycerol } \\
\text { Glycerol } \\
\text { Glycerol } \\
\text { Glucose } \\
\text { Glucose }\end{array}$ & $\begin{array}{l}\text { None } \\
\text { Galacturonate } \\
\text { PGA } \\
\text { None } \\
\text { PGA }\end{array}$ & $\begin{array}{l}0.15 \\
0 \cdot 43 \\
1 \cdot 12 \\
0 \cdot 13 \\
0.55\end{array}$ \\
\hline I & P45 & $\mathrm{P} 0, \mathrm{P} 2, \mathrm{P} 2 \mathrm{l}$ & $\begin{array}{l}\text { Glycerol } \\
\text { Glycerol } \\
\text { Glycerol } \\
\text { Glucose } \\
\text { Glucose }\end{array}$ & $\begin{array}{l}\text { None } \\
\text { Galacturonate } \\
\text { PGA } \\
\text { None } \\
\text { PGA }\end{array}$ & $\begin{array}{l}1 \cdot 16 \\
0 \cdot 95 \\
1 \cdot 10 \\
0 \cdot 21 \\
0 \cdot 56\end{array}$ \\
\hline II & P52 & $\begin{array}{l}\text { P1, P5, P19, P28, P29, P30, } \\
\text { P39, P40, P44, P47, P51, P53 }\end{array}$ & $\begin{array}{l}\text { Glycerol } \\
\text { Glycerol } \\
\text { Glycerol } \\
\text { Glucose } \\
\text { Glucose }\end{array}$ & $\begin{array}{l}\text { None } \\
\text { Galacturonate } \\
\text { PGA } \\
\text { None } \\
\text { PGA }\end{array}$ & $\begin{array}{l}0 \cdot 61 \\
1 \cdot 16 \\
4 \cdot 53 \\
0 \cdot 35 \\
2 \cdot 36\end{array}$ \\
\hline III & P57 & $\begin{array}{l}\text { P6, P10, P13, P23, P25, } \\
\text { P26, P56, PC }\end{array}$ & $\begin{array}{l}\text { Glycerol } \\
\text { Glycerol } \\
\text { Glycerol } \\
\text { Glucose } \\
\text { Glucose } \\
\text { Glucose }\end{array}$ & $\begin{array}{l}\text { None } \\
\text { Galacturonate } \\
\text { PGA } \\
\text { None } \\
\text { Galacturonate } \\
\text { PGA }\end{array}$ & $\begin{array}{l}0.47 \\
1.53 \\
3.21 \\
0.48 \\
1.42 \\
1.73\end{array}$ \\
\hline
\end{tabular}

* Strains were grown in minimal medium with glycerol as carbon source, with or without an inducer of pectinolysis.

$\dagger$ Assayed at the end of the exponential phase; specific activity is expressed as $\mu$ mol unsaturated products min $^{-1}$ (mg bacterial dry weight $)^{-1}$. Each experiment was repeated at least three times and representative results are shown.

Analysis of the mutants. The 26 mutants affected in PL production were purified and then assayed for PL activity under various growth conditions (Table 2). All these mutations allowed PL to be produced at a higher level in the absence of the inducer. However, they showed various derepressed levels and different responses to the presence of inducer or glucose in the culture medium. Three types of mutants could be differentiated (Table 2). In mutants of class I, the noninduced level of PL activity was similar to the PGA-induced level of the wild-type strain. The same level was found in the presence of an inducer (galacturonate or PGA), but glucose caused a strong repression. Mutants of class II were 'super-inducible' in the presence of galacturonate or PGA. They were also repressed by glucose. Mutants of class III were also 'super-inducible', but their PL synthesis, noninduced or induced, was less sensitive to repression by glucose.

Formation of catabolite-repression-sensitive proteins in the mutants of class III. To clarify the decreased glucose repression of PL synthesis in the mutants of class III, we investigated the synthesis of two other proteins which are sensitive to glucose repression (Hugauvieux-CottePattat et al., 1983; Hugouvieux-Cotte-Pattat \& Robert-Baudouy, 1985b). The formation of $\beta$ galactosidase and of the hexuronate transport system was less sensitive to glucose repression (Table 3) in these mutants than it was in mutants of class I or II or in the parental strain. Synthesis of various independent proteins thus appeared partially resistant to catabolite repression exerted by glucose in these mutants, which were designated cri (for cataboliterepression-insensitive).

Growth of the mutants and $P L$ formation. When grown in liquid culture on glycerol minimal medium with or without PGA, the wild-type strain B374 exhibited increased PL activity at the end of exponential growth. This was also observed for mutants of classes II or III (Fig. 1). Thus the mechanism controlling the activation of PL synthesis during growth was not altered by the cri mutations. In contrast, for strains of class I, PL production strictly followed the growth curve (Fig. 1); PL activity remained proportional to the bacterial density and the specific activity was 

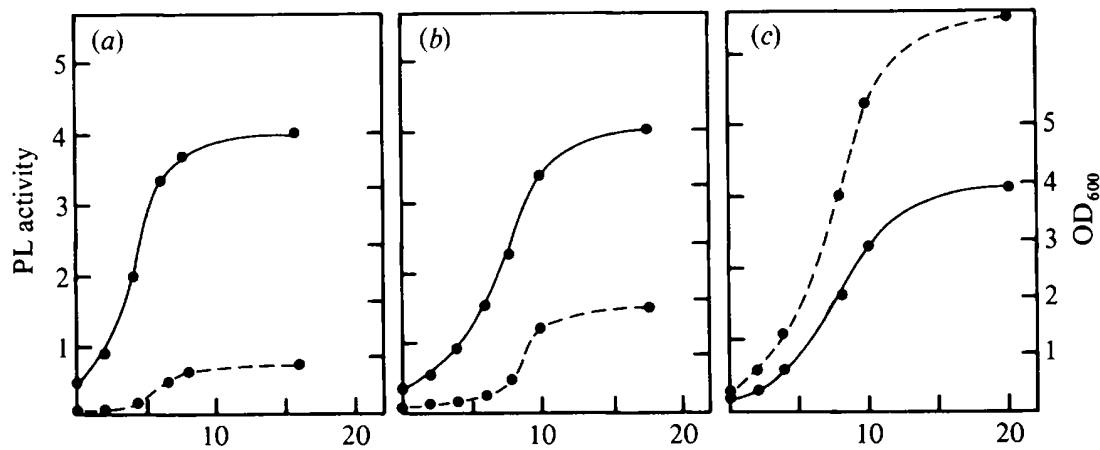

Culture time $(\mathrm{h})$

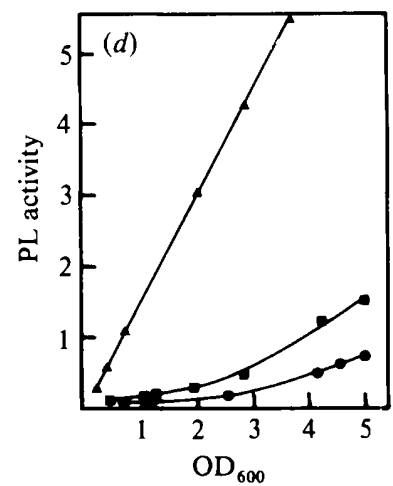

Fig. 1. Regulation of PL synthesis during growth. Growth $\left(\mathrm{OD}_{600},-\right)$ and PL activity $(\mu \mathrm{mol}$ unsaturated products min $^{-1}$ per $100 \mu$ l of culture, ---) were measured in liquid cultures in glycerol minimal medium for strains B374 (wild-type, $a$ ), P56 (class III mutant, $b$ ) and P0 (class III mutant, $c$ ). In $(d)$ the data in $(a)$ to $(c)$ are plotted to show the relation between growth and PL activity: O, B374;

, P56; $\Delta$, P0. The experiment was done at least three times for each strain; the values shown are from one experiment.

Table 3. Synthesis of various proteins in the PL constitutive mutants

\begin{tabular}{|c|c|c|c|c|}
\hline \multirow[b]{2}{*}{ Strain* } & \multirow[b]{2}{*}{$\begin{array}{l}\text { Growth } \\
\text { conditions } †\end{array}$} & \multicolumn{3}{|c|}{ Specific activity $\ddagger$} \\
\hline & & PL & $\begin{array}{c}\beta \text {-Galacto- } \\
\text { sidase }\end{array}$ & $\begin{array}{c}\text { Hexuronate } \\
\text { transport system }\end{array}$ \\
\hline BL4 & $\begin{array}{l}\text { Glycerol } \\
\text { Glycerol + inducer } \\
\text { Glucose } \\
\text { Glucose + inducer }\end{array}$ & $\begin{array}{l}0.14 \\
0.51 \\
0.10 \\
0.33\end{array}$ & $\begin{array}{r}2 \\
125 \\
1 \\
2\end{array}$ & $\begin{array}{r}3 \\
23 \\
2 \\
8\end{array}$ \\
\hline P57 & $\begin{array}{l}\text { Glycerol } \\
\text { Glycerol + inducer } \\
\text { Glucose } \\
\text { Glucose + inducer }\end{array}$ & $\begin{array}{l}0.47 \\
1.53 \\
0.48 \\
1.42\end{array}$ & $\begin{array}{r}1 \\
160 \\
1 \\
95\end{array}$ & $\begin{array}{r}3 \\
22 \\
3 \\
15\end{array}$ \\
\hline P45 & $\begin{array}{l}\text { Glycerol } \\
\text { Glycerol + inducer }\end{array}$ & $\begin{array}{l}1 \cdot 16 \\
0.95\end{array}$ & $\begin{array}{r}2 \\
133\end{array}$ & $\begin{array}{r}7 \\
18\end{array}$ \\
\hline
\end{tabular}

* The parental strain BL4 is a $\mathrm{Lac}^{+}$derivative of the wild-type strain B374, P57 is a cri mutant (class III) and P45 is a gpi mutant (class $\mathrm{I}$ ).

$\dagger$ Strains were grown in minimal medium with glycerol or glucose as carbon source, with or without an inducer for the corresponding enzyme synthesis. The inducers were lactose for $\beta$-galactosidase and galacturonate for PL and for the hexuronate transport system.

$\ddagger$ Specific activities are expressed in $\mu \mathrm{mol} \mathrm{min}^{-1}\left(\mathrm{mg} \text { dry weight) }{ }^{-1} \text { for PL, in } \mathrm{U} \text { (mg dry weight }\right)^{-1}$ for $\beta$ galactosidase and in $\mathrm{nmol} \mathrm{min}^{-1}(\mathrm{mg} \text { dry weight })^{-1}$ for the hexuronate transport system. Each experiment was repeated at least three times and representative results are shown.

independent of the growth phase. This indicates that the mutations of class I altered the mechanism controlling the activation of PL synthesis at the end of exponential growth. These mutants were designated gpi (for growth-phase-independent). 
Cellulase and protease formation in the mutants. Preliminary experiments indicated that the production of extracellular cellulases and proteases was increased in some of the mutants (data not shown). In the gpi mutants, only cellulase synthesis was increased. This probably resulted from the loss of control of the mechanism regulating the temporal activation of PL and cellulases, the synthesis of which is coincident during growth (Andro et al., 1984). The cri mutations caused a strong increase in both cellulase and protease synthesis, in glycerol or glucose minimal medium. cri mutations thus apparently confer a non-specific glucose resistance to the synthesis of the three secreted proteins, PL, cellulases and proteases.

Soft-rot of potato tubers. The wild-type strain B374 had no effect in the potato tuber disc assay, but all the mutants caused considerable soft-rot of the tissues (data not shown).

Identification of the PL isoenzymes expressed in the mutants. Cell extracts of the mutants grown in glycerol minimal medium were fractionated on a polyacrylamide electrofocusing gel and stained for pectolytic activity. The profiles of each mutant contained the five isoenzymes PLa, PLb, PLc, PLd and PLe (with isoelectric points of $4.7,7 \cdot 7,8.3,9.5$ and 9.8 respectively), corresponding to the PL forms present in extracts of the wild-type strain grown in the presence of PGA. However, some changes in the relative amount of each isoenzyme were noticed. In extracts of the non-induced wild-type strain, only the PLe band was clearly visible, whereas the other PL bands were very faint. For the gpi mutants, the three bands corresponding to PLa, PLd and PLe became clearly visible. In contrast, for the cri mutants, PLb and PLc appeared to be synthesized in larger amounts than in the wild-type.

Relation with KDG catabolism. We noticed that P45, a mutant of class I, was able to grow on KDG as carbon source, which the wild-type strain cannot do. Mutants able to use KDG normally show a derepressed expression of $k d g T$, which encodes a KDG transport system. This phenotype results from a mutation either in the promoter region of $k d g T$ or in the regulatory gene $k d g R$ controlling the expression of $k d g T$ (G. Condemine, unpublished). In $k d g R$ mutants, two other genes involved in KDG catabolism, $k d g K$ and $k d g A$ (Hugouvieux-Cotte-Pattat \& Robert-Baudouy, 1985a) are also constitutively expressed. Analysis of strain P45 revealed that it contains an inactivated $k d g R$ gene. Two new spontaneous $k d g R$ mutants of strain A733 were obtained on KDG minimal medium. Both showed constitutive synthesis of PL and their pattern of PL synthesis was identical to that of the gpi mutants.

Localization of the mutations. Mapping the different constitutive mutations was achieved by using RP4::mini-Mu plasmid pULB113 (Van Gijsegem \& Toussaint, 1982), which can mobilize the chromosome of its host from random points of origin. The plasmid was transferred into the constitutive mutants, which were then mated with the polyauxotrophic strain RH6010. Transconjugants which had acquired the prototrophic allele for one of these markers were selected and tested for the constitutive synthesis of PL. The percentage of cotransfer between the constitutive mutation and the markers permitted us to determine the linkages between them. The cri mutations of class III mutants P56 and P57 cotransferred at $1 \%$ with the ile marker and about $20 \%$ with $t h r$ and leu. According to the previous location of these three markers (Schoonejans \& Toussaint, 1983) the gene order in this region is ile-cri-thr-leu. The gpi mutations of class I mutants $\mathrm{P} 0$ and $\mathrm{P} 45$ cotransferred at $0.5 \%$ with pro, $3 \%$ with his and $8 \%$ with trp. The trp and his markers were previously shown to cotransfer at about $30 \%$ (Schoonejans \& Toussaint, 1983) and the $k d g A$ gene is located between them (Van Gijsegem $e t$ al., 1985a). The gpiR mutants were then mated with the $k d g A$ strain ERH202. The cotransfer between $g p i R$ and $k d g A$ was $4 \%$. These results suggest that the order of the markers in this region is pro-gpiR-trpkdgA-his.

\section{DISCUSSION}

No derepressed mutations of PL synthesis have previously been described. We have isolated and characterized three types of mutants of E. chrysanthemi strain B374 with derepressed synthesis of PL. 
Mutants of class III (cri) are distinct from the wild-type and from the other mutants in their catabolite repression profile. In the wild-type strain, and in mutants of class I or II, PL activity decreased in the presence of glucose, showing a catabolite repression exerted by this sugar. The full expression of the pel genes, like that of several other genes involved in the catabolism of sugars (Ullman \& Danchin, 1983; De Combrugghe et al., 1984), probably requires the action of the CAP protein and cAMP. The cri mutations allowed the pel genes to be expressed at a very high level even in the presence of glucose, indicating that PL formation was resistant to catabolite repression by glucose. Separation of PL isoenzymes by electrofocusing indicated that PLb and PLc were the isoenzymes most strongly expressed in these mutants. The synthesis of these two isoenzymes is thus probably more sensitive to catabolite repression than that of the other isoenzymes. The release from catabolite repression affected not only PL but also other known catabolite-repressible proteins, viz. $\beta$-galactosidase and the hexuronate transport system. Moreover, the synthesis of protease and cellulase was strongly enhanced in the cri mutants, suggesting that the formation of these secreted proteins is sensitive to glucose repression.

Mutants of class I ( $g p i)$ showed a high constitutive PL activity, similar to the induced activity of the wild-type strain. The lack of regulation of PL synthesis in these mutants is evident if we compare the induction ratios by PGA: about 10 for the wild-type, versus $1-1.5$ for the derepressed gpi mutants. This suggests the inactivation of a regulatory gene responsible for induction of PL synthesis in the presence of PGA. Electrofocusing revealed that three PL isoenzymes, PLa, PLd and PLe, were constitutively synthesized in these mutants.

The next question was whether the gpi mutations conferring constitutivity were linked to the structural genes for PL. The gpi mutations mapped near trp and his while the pel genes that encode PL are located between ile and $t h r$ (Van Gijsegem et al., 1985); the gpi mutations are thus unlinked to the pel genes. It seems likely that these mutations occurred in a true regulatory gene, and we propose to name this gene $g p i R$. The gpiR regulatory gene also controls the mechanism which allows the cell to synthesize PL when the cells encounter poor growth conditions, such as in the stationary phase. The gpiR mutants showed no alteration in their catabolite repression profiles, demonstrating that the growth phase dependence of PL synthesis is controlled by a mechanism other than catabolite repression. This conclusion is confirmed by analysis of the catabolite-repression-insensitive mutants of class III, which are not affected in the timing of PL activation during growth. The fact that inactivation of the gpiR gene led to constitutive synthesis of proteins is evidence for $g p i R$ acting as a negative regulatory gene. The gpiR regulatory gene controls, directly or indirectly, two events: the dependence of PL synthesis on growth phase and the ability of galacturonate or PGA to induce PL synthesis.

Inactivation of $k d g R$, the regulatory gene controlling the expression of the three genes specifically involved in KDG catabolism, $k d g T, k d g K$ and $k d g A$, also led to a derepressed synthesis of PL. The $k d g R$ mutations showed effects identical to gpiR mutations. However, these two genes are probably distinct since not all gpiR mutants showed a $\mathrm{KdgR}^{-}$phenotype. The role of $k d g R$ in the regulation of PL synthesis remains to be clarified.

Mutants of class II showed various basal levels of PL activity with values between the noninduced and the induced level of the wild-type strain. PL synthesis remained inducible, with induction ratios of 10-20. So the major regulator gene, responsible for PL induction, is present in these strains. This class is the least well characterized and may be heterogeneous.

A common property of the constitutive mutants of the three classes is their increased softrotting of potato tuber tissue. Mutants of classes II and III, which had 'super-induced' levels of $\mathrm{PL}$ in the presence of PGA, produced about 10 times more PL activity than the wild-type strain. Since PL of $E$. chrysanthemi causes soft-rot of plant tissue, the increase in PL synthesis may account for this phenomenon.

The isolation of such constitutive mutants opens a new area in the analysis of the regulatory mechanisms governing the pectinolysis of E. chrysanthemi. This work confirms, at the genetic level, the existence of the three types of regulation affecting PL synthesis which were suggested by physiological studies (catabolite repression, growth phase dependence and induction by PGA derivatives). We identified two distinct regulatory systems. The first regulatory system is a general mechanism and has multiple effects on the cells. The catabolite-insensitive cri mutations 
affected, at least, the synthesis of PL, cellulases, proteases, the hexuronate transport system and $\beta$-galactosidase. The second regulatory system is mediated by the gpiR product, and is responsible for two types of control. gpiR, whose product leads to PL synthesis dependent on the growth phase and inducible by PGA degradation products, probably acts as a negative regulatory gene with two effectors, one in PGA catabolism and the other present during limiting growth conditions. We are currently testing the validity of this hypothesis by cloning the wildtype allele of the gpiR gene from a genomic library of strain B374 (Reverchon et al., 1985).

The various pel genes are subject at different levels to each type of regulation. In the wild-type strain, pelE has a high basal level while pelA, pelB, pelC and pelD are strongly inducible. Analysis of gene fusions (S. Reverchon, unpublished) has recently confirmed this type of regulation for pelE, pel $A$ and pelD. The cri mutations mainly affect the pelB and pelC genes while pelA, pelD and pelE are affected more by the $g p i R$ and $k d g R$ mutations. These different regulation patterns may reflect the contribution of each PL isoenzyme to the pathogenicity of $E$. chrysanthemi.

This work was supported by grants from the Ministère de la Recherche et de l'Industrie (Aide à la Recherche en Biologie Moléculaire), and from the Commission of the European Communities (Biomolecular Engineering Program). We thank L. Fryer, S. Sullivan and J. Hughs for reading the manuscript, and F. Stoeber, in whose laboratory this work was done. We also thank J. P. Chambost, A. Kotoujansky, A. Toussaint and their co-workers for the exchange of unpublished information about Erwinia chrysanthemi.

\section{REFERENCES}

Andro, T., Chambost, J. P., Kotoujansky, A., Cattaneo, J., Bertheau, Y., Barras, F., Van GiJsegem, F. \& Coleno, A. (1984). Mutants of Erwinia chrysanthemi defective in secretion of pectinase and cellulase. Journal of Bacteriology 160, 11991203.

Bashman, H. \& Bateman, D. (1975). Relationship of cell death in plant tissue treated with a homogeneous endopectate lyase to cell wall degradation. Physiological Plant Pathology 5, 249-262.

BertheaU, Y., MadGidi-Hervan, E., Kotoujansky, A., Nuuyen-The, C., Andro, T. \& Coleno, A. (1984). Detection of depolymerase isoenzymes after electrofocusing or in titration curves. Analytical Biochemistry 139, 383-389.

Chatterjee, A. \& Starr, M. (1980). Genetics of Erwinia species. Annual Review of Microbiology 34, 645-676.

Collmer, A. \& Bateman, D. (1981). Impaired induction and self-catabolite repression of extracellular pectate lyase in Erwinia chrysanthemi mutants deficient in oligo-galacturonide lyase. Proceedings of the National Academy of Sciences of the United States of America 78, 3920-3924.

Condemine, G., Hugouvieux-Cotte-Pattat, N. \& RoBert-BaudouY, J. (1984). An enzyme in the pectinolytic pathway of Erwinia chrysanthemi: 2keto-3-deoxygluconate oxidoreductase. Journal of General Microbiology 130, 2839-2844.

Condemine, G., Hugouvieux-Cotte-Pattat, N. \& ROBERT-BAUDOUY, J. (1986). Isolation of Erwinia chrysanthemi $k d u D$ mutants altered in pectin degradation. Journal of Bacteriology 165, 937-941.

De Crombrugghe, B., Busby, S. \& Buc, H. (1984). Cyclic AMP receptor protein: role in transcription activation. Science 224, 831-838.

Hamon, Y. \& Peron, Y. (1961). Les propriétés antagonistes réciproques parmi les Erwinia. Discussion de la position taxonomique de ce genre. Comptes rendus des séances de l'Académie des sciences 235 , 913-915.

Hubbard, J., Williams, J., Niles, R. \& Mount, M. (1978). The relation between glucose repression and endo-polygalacturonate trans-eliminase and adenosine $3^{\prime}: 5^{\prime}$-cyclic monophosphate levels in Erwinia carotovora. Phytopathology 68, 95-99.

HugouvieuX-Cotte-Pattat, N. \& Robert-Baudouy, J. (1985a). Isolation of $k d g K-l a c$ and $k d g A-l a c$ gene fusions in the phytopathogenic bacterium Erwinia chrysanthemi. Journal of General Microbiology 131, 1205-1211.

HugouvieuX-CotTe-Pattat, N. \& Robert-Baudouy, J. (1985b). Lactose metabolism in Erwinia chrysanthemi. Journal of Bacteriology 162, 248-255.

HugouvieuX-Cotte-Pattat, N., Quesneau, Y. \& RoBERT-BAUdOUY, J. (1983). Aldohexuronate transport system in Erwinia carotovora. Journal of Bacteriology 154, 663-668.

MIlleR, J. H. (1972). Experiments in Molecular Genetics. Cold Spring Harbor, NY: Cold Spring Harbor Laboratory.

MORAN, F. \& STARR, M. (1969). Metabolic regulation of polygalacturonic acid trans-eliminase in Erwinia. European Journal of Biochemistry 11, 291295.

Moran, F., NASUno, S. \& StarR, M. (1968). Extracellular and intracellular polygalacturonic acid transeliminase of Erwinia carotovora. Archives of Biochemistry and Biophysics 123, 298-306.

ReVerchon, S., Hugouvieux-Cotte-Pattat, N. \& RoBert-Baudouy, J. (1985). Cloning of genes encoding pectolytic enzymes from a genomic library of the phytopathogenic bacterium, Erwinia chrysanthemi. Gene 35, 121-130.

Schoonejans, E. \& Toussaint, A. (1983). Utilization of plasmid pULB113 (RP4 : : mini-Mu) to construct a linkage map of Erwinia carotovora subsp. chrysanthemi. Journal of Bacteriology 154, 1489-1492. 
Stark, M. \& Chatterjee, A. (1972). The genus Erwinia: enterobacteria pathogenic to plants and animals. Annual Review of Microbiology 26, 389-426.

Ullman, A. \& Danchin, A. (1983). Role of cyclic AMP in bacteria. Advances in Cyclic Nucleotide Research 15, 1-53.

Van Gijsegem, F. \& Toussaint, A. (1982). Chromosome transfer and R' formation by an RP4::miniMu derivative in Escherichia coli. Salmonella typhimurium, Klebsiella pneumoniae and Proteus mirabilis. Plasmid 7, 30 44 .

Van Gijsegem, F. \& Toussaint, A. (1983). In vivo cloning of Erwinia carotovora genes involved in the catabolism of hexuronates. Journal of Bacteriology 154, 1227-1235.
Van Gujegem, F., Hugouvieux-Cotte-Pattat, N. \& ROBERT-BAUDOUY, J. (1985a). Isolation and characterization of Erwinia chrysanthemi mutants defective in degradation of hexuronates. Journal of Bacteriology 161, 702-708.

Van Gijsegem, F., Toussaint, A. \& Schoonejans, E. $(1985 b)$. In vivo cloning of the pectate lyase and cellulase genes of Erwinia chrysanthemi. EMBO Journal 4, 787-792. 